\title{
Interrogating the Socio-Cultural Experiences of the Urhobo People in the Urhobo Disco Music and the Role of the Radio Media
}

Interrogating the Socio-Cultural Experiences of the Urhobo People in the Urhobo Disco Music and the Role of the Radio Media

\begin{abstract}
Often times, music has been seen as an art form which embodies and boasts a lot of rich socio-cultural experiences and expressions. More so, is the Urhobo music which embodies so many cultural values that are impalpable yet so much cherished. It is observed that the traditional music of the Urhobo, which includes the Urhobo Disco music by Okpan Arhibo, is used in various socio-cultural contexts such as burials, in-law greetings, marriages, birthday and naming ceremonies, amongst others. It is the concern of this paper, therefore, to investigate the effectiveness of the role of the radio in broadcasting music, particularly of the Urhobo of Delta State, Nigeria, as a way of promoting the socio-cultural experiences of the Urhobo nationality. The paper adopts both the phenomenological and cultural schema theories. The descriptive survey research design is also employed to enable the collection of data from the Management of JFM Radio $(95.1 \mathrm{fm})$ and Melody FM (88.6fm), as well as twenty-six participants that were engaged in interview sessions, using a Self-responded Interview Questionnaire of ten validated items involving the Likert moderated type rating scale of four points. Generated data were subjected to simple statistics of the mean and standard deviation. Findings show that the compendium of Urhobo music by radio stations enables the spread of the cultural and social experience of the Urhobo people beyond their region. The paper concludes that radio broadcast of traditional music ensures that the cultural experience of the Urhobo is sustained. Hence, the paper recommended that radio stations should give sufficient airtime for the broadcast of Urhobo Disco music. This will allow for the spread of the Urhobo experience in Delta State, Nigeria.
\end{abstract}

\section{Keywords}

Disco Music, Urhobo People, Radio, Socio-Cultural Experiences, Media 


\section{Introduction}

Experience as discussed in this paper focuses on music and its contexts, which is a platform for expressing and exposing socio-cultural norms, practices and events. This study, however, is carried out with particular reference to and focus on Urhobo Disco music, which is a genre type among Urhobo musicians. Urhobo Disco is a distinct Urhobo music genre performed by notable Urhobo musicians such as Chief Okpan Arhibo, who popularized the type. The exhibition of experiences by the Urhobo people through a medium as music is an aspect of the African cultural experiences as a whole. According to the IGI Global (2020), cultural experiences imply activities or environments wherein individuals interact with other individuals from different cultures and settings. The understanding drawn from the definition suggests that a people's experiences are culturally based and that these experiences are the basis for social interaction, and that it is found in varied contexts. The underlining element in the above definition suggests that experiences emanate from the culture of a people. It consists of the customs, arts and social interactions of a particular nation, people or other social groups. In this study the Urhobo ethnicity is being examined in relation to her customs, arts and social interactions, with particular attention to the use of music as showcased by Urhobo musicians.

It is pertinent to mention that Urhobo music consists of different genres, which include Udje music, Igoru music, Opiri music, Ema music, Opre music, Adjuya music and, most recently, Urhobo Disco music. Each of the listed Urhobo music genres are engaged as an entertainment medium employed by Urhobo musicians to convey the socio-cultural experiences of the Urhobo people. All of these musical genres may be performed during burials, marriage ceremonies, chieftaincy title taking events, church services, political rallies, birthday ceremonies, naming ceremonies, and so on. They also serve as a source of relaxation in the home among family members, especially, when the recorded Urhobo music is played through the radio and other media devices. Many broadcasting stations, public and private, boast a large compendium of Urhobo music. They are often aired as programmes of their own, during other programmes, and during special periods and events of the year that commemorate the experiences of the Urhobo people. The compilation of Urhobo music genres by broadcasting stations indicates that the broadcasting industry recognizes and acknowledges the cultural values and social experiences of the Urhobo people. More importantly, airing Urhobo music on radio gives the genres a wider coverage and audience across the shores of the Urhobo nation. Therefore, through such broadcasts the Urhobo people are able to share their socio-cultural experiences embedded in the melodious Urhobo music genres with other ethnic groups. Dawn Joseph values the broadcast of music 
as a medium for promoting cultural diversification globally ${ }^{1}$. The United Nations Education Scientific Organization also supports the view that music broadcast through radio enhances the spread of cultural values and information that may be seen as an intangible cultural heritage of a people ${ }^{2}$. It is imperative to aver here that most Urhobo music genres, including Urhobo Disco music, contains some identified impalpable cultural values that are highly cherished by the Urhobo people. It is against the foregoing that this paper attempts to underscore and interrogate the role of the radio media in the popularization of the Urhobo Disco music, as well as, the socio-cultural experiences of the Urhobos in the Urhobo Disco music genre. The choice of Urhobo disco stems from its recent creation in the Urhobo music corpus.

Experts in music media have observed that most radio stations are concerned with the broadcast of popular music on radio. However, general observation points one to the fact that many radio stations in Delta State, for instance, have a compendium of foreign popular music more than those of Urhobo music genres. Peter, John Dawn is of the opinion that popular music broadcast is dominating the airwave to the neglect and detriment of cultural music. This is despite the fact that many of the radio stations are situated in places with a majority of the people coming from a culturally-based setting ${ }^{3}$. Popular music is quite associated with waywardness, prostitution, illicit sex, broken homes, and unwanted pregnancies, respectively. In contrast, the authors show that cultural music reflects certain things about the place or environment of the musician that is capable of linking the audience to her cultural identity through the radio music broadcast. Another contentious view against popular music is that the songs are meant to appeal to demographics comprising mainly young people. More so, the consequence of neglecting cultural music altogether would herald the gradual deterioration of Urhobo music and gradual extinction of the same. Thus, arising from this observed problem, many Urhobo musicians attempt to bridge the gap by introducing the element of popular music genre, Disco, to appeal to the young generation of Urhobo people; Disco music is often performed in clubs or parties

No doubt, the radio, being a medium of mass communication, serves as one of the best platforms for cultural education, awareness campaign and social mobilization. However, the broadcast of Urhobo Disco music on radio has not been given sufficient attention and assessment in the literature of music media. The dearth

\footnotetext{
${ }^{1}$ J. Dawn, Promoting Cultural Diversity: African Music in Australian Teacher Education, "Australian Journal of Music Education" 2016, 50 (2).

${ }^{2}$ UNESCO, Performing Arts (Such as Traditional Music, Dance and Theatre), 2016, https://ich. unesco.org/en/performing-arts-00054 [access: 30.03.2021].

3 J. Dawn, Promoting Cultural Diversity: African Music in Australian Teacher Education, "Australian Journal of Music Education" 2016, 50 (2).
} 
of studies on the subject has made it difficult to ascertain the extent to which one understands the compendium of Urhobo Disco music among the select public and private radio stations under investigation. The general objective of this paper, therefore, is to ascertain the extent to which radio stations in Delta State airs Urhobo Disco music. The specific objectives of the investigation are to determine the compilation (compendium) of Urhobo music available for broadcast in the select radio stations under investigation, examine the difference between Urhobo Disco music and pop music in the context of cultural experiences of the Urhobo people, examine the influence of Urhobo Disco music genre on the social experience of the Urhobo people, evaluate the extent to which Urhobo music has contributed to the cultural experiences of Urhobo people, and to investigate the broadcast of Urhobo Disco music in relation to the transmission of cherished values, norms and experiences of the Urhobo people.

In order to achieve the stated specific objectives of this paper, the descriptive survey research design involving both the qualitative and quantitative research approaches are employed. The application of both approaches is informed by the fact that data were collected from sample respondents through research instruments. Interviews, phone calls and interactive session were also engaged. The data collected are subjected to rating scale for the purpose of evaluation and measurement of responses of the select respondents. The primary source results are subjected to discussion using content analytical method based on secondary (literature exploration) data submission and deduction respectively. Tables of simple mean and standard deviation are utilized to explain the frequency table of responses on the questionnaire instrument developed for the purpose.

\section{A Concise Retrospect on the Urhobo People}

Urhobo is an ethnic group that is located in Delta State, Nigeria. It has twenty four kingdoms, with hundreds of communities. According to Stephen Okpadah in Aesthetic Language of Communication in Urhobo Culture, Urhobo remains the biggest ethnic group in Delta state, and the fifth biggest in Nigeria, after Hausa, Yoruba, Igbo and Ijaw ${ }^{4}$. The ethnic group is surrounded by other ethnic nationalities such as the Itsekiri, Ijaw, Igbo, Benin and Isoko. Also, it is an oil producing ethnic group, bedeviled with environmental despoliation by multinational oil companies. The culinary tradition of the Urhobo people is fabulous. Delicacies such as Owho Soup,

${ }^{4}$ S. Okpadah, Language of Communication in Urhobo Culture, [in:] K. Eni, B. Binebai, S. Ikibe (eds.), Music Scholarship, Culture and Performance Challenges in $21^{\text {st }}$ Century Africa: A Critical Resource Book in Honour of Emurobome Idolor, Lagos 2016. 
Banga Soup, Starch, among others, serve as food for the Urhobo people 5 . Numerous music and dance traditions abound among the Urhobo people. These include the Udje, Ema, Idjurhi, among others.

\section{Theoretical Framework}

The study is anchored on the phenomenological theory and the cultural schema theory. The phenomenological theory posits that obtaining accurate knowledge of another person requires the understanding of how that person experiences the world. Researches attribute the author of this theory to Edmund Husserl (18591938), who established phenomenology at first as a kind of descriptive psychology and later as a transcendental and eidetic science of consciousness. This theory lays the foundation for the investigation relating to human experience involving the culture of an ethnic group. Adogbo and Ojo find the theory useful for researchers in the faculty of arts, whose area of specialty consists of religion, music, theatre arts, amongst others ${ }^{6}$. They recommend the theory for an investigation of this sort because it enables researchers to employ a method that attempts to explicate the "inner experiences" of people. According to the authors, the theory develops into a method of research in the humanity. They consider the phenomenological approach relevant because its mainstream tendency is to employ what the phenomenologist call epoch and eidetic vision. This approach is most useful to this type of investigation because when using the phenomenological approach, one does not speak as a sociologist, theologian or a philosopher but as a living individual observing an event in the world. The basis for honest humanity and honest communication resides in the ability of the researcher to report the views of the respondents and not his pre-established criteria ${ }^{7}$.

The implication of the above statement is that the phenomenological theory is an acceptable approach applicable to the investigation involving the Urhobo people's experiences while listening to the Urhobo Disco music which embodies aspects of the cultural experiences of the Urhobo people. The researcher also discovers that the theory aligns with the general objective this paper as it provides the roadmap and information such as the appropriate design adopted for the purpose of primary data collection that have assisted the understanding of the Urhobo people's experience as expressed in the Urhobo Disco music. Thus, the phenomeno-

${ }^{5}$ S. Okpadah, Urhobowood Home Videos and the Poetics of cultural documentation, [in:] M. Tugbokorowei, C. Anyanwu (eds.), New Aesthetic Dimensions in African Drama and Theatre: A Festschrift in Honour of Prof Sam Ukala, Delta State 2018.

${ }^{6}$ M. Odogbo, E. Ojo, Research Methods in the Humanities, Lagos 2003.

7 Ibidem. 
logical theory is adopted alongside the cultural schema theory since the phenomenological theory tends towards a cultural explanation of cultural experiences.

Nishida proposes the cultural schema theory as a framework for culture-related investigation, including cultural experience ${ }^{8}$. Shahghasemi avers that the theory suggests that human beings employ classifications to understand members of other cultures, and add new data to previously available categories'. Malcolm and Shanfian find that the schema theoretical framework is relevant to cultural studies dealing with human experiences in society that can be perceived, observed and documented. According to the authors, the experiences which are unique to individuals allow them to acquire personal schemas ${ }^{10}$. That societal schema may emerge from a group's collective knowledge and are represented across minds in a society, enabling people to think as if they are of one mind. In other words, the concept of comprehension is developed from this theory. This is because schemas are generalized collections of knowledge of past experiences that are organized into related knowledge groups; they guide our behaviours in familiar situations.

The study by Attamba and Forsythe recommends this theory for the processing of cultural experiences. In their view, schema is incorporated in culture because it entails comprehension processes ${ }^{11}$. They find that prior knowledge and cultural background greatly influence comprehension processes. That, individuals may comprehend information better when they are culturally familiar with the information; that is, when they have the appropriate cultural schemata. This concept is referred to in the study by Jacob Strandell as culture cognition interaction ${ }^{12}$. By implication, subjecting the cultural elements of a group to assessment allows for a better understanding of the practice of the identified cultural heritage, such as the cultural experience of the Urhobo people in the Urhobo Disco music.

\section{The Concept of Culture and Cultural Experience}

There is no universally accepted definition of culture. Most of the definitions of the term are dependent on the proponents. For instance, Hofstede says that cul-

\footnotetext{
${ }^{8}$ H. Nishida, Cultural Schema Theory, [in:] W. Gudykunst (ed.), Theorizing about Intercultural Communication, Thousand Oaks 1999.

${ }^{9}$ E. Shahghasemi, Cultural Schema Theory, [in:] Y. Kim, K. McKay-Semmler (ed.), The International Encyclopedia of Intercultural Communication, vol. 1, New York 2018.

${ }^{10}$ I.G. Malcolm, F. Sharifian, Aspect of Aboriginal English Oral Discourse: An Application of Cultural Schema Theory, "Discourse Studies" 2002, 4 (2).

${ }^{11} \mathrm{~J}$. Altanba, W. Forsythe, The Role of Cultural Schemata in Reading Comprehension, "Advances in Psychology" 1993, 103.

12 J. Strandell, The Cultural Schema: Towards Conceptual Compatibility in Culture-Cognition Interaction Research, Doctoral dissertation, University of Copenhagen, Copenhagen 2017.
} 
ture refers to the commutative deposit of knowledge, experience, beliefs, values, attitudes, meaning, religion, hierarchies, notion of time, roles, spatial relations, concepts of the universe and material objects and possessions acquired by a group of people in the course of generations through individual and group striving ${ }^{13}$. This definition seems to capture nearly all the attributes that could be found in a culture. Some of the constituent of culture identified in the definition includes the experience of a group of people such as an ethnic group. The definition appears to align with the commonly held definition that defines culture as a way of life of a group of people. It defines the people's behaviour, beliefs, values and symbols that they accept generally without thinking about them and that are passed around by communication and imitation from one generation to the next. A similar definition states that culture is the sum total of the learned behaviour of a group of people that are generally considered to be the tradition of that people and are transmitted from generation to generation. The implication from the above definition points to the fact that culture is experiential and tangible in human society. It is practically demonstrable, shared, treasured, inherited, recorded and exported in form of tourism, trade, interaction and encouraged by the people.

The definition of culture by Kim Ann Zimmermann states that culture is the characteristics and knowledge of a particular group of people, encompassing language, religion, cuisine, social habits, music and $\operatorname{arts}^{14}$. Thus, culture dynamics is experienced through religion, food, what we wear, how we wear it, our language, marriage, music, what we belief is right or wrong, how we sit at the table, how we greet visitors, how we behave with loved ones, and a host of other things ${ }^{15}$. The Center for Advanced Research on Language Acquisition discovers that cultural experience is the shared patterns of behaviours and interactions, cognitive constructs and affective understanding that are learnt through a process of socializa$\operatorname{tion}^{16}$. These shared patterns identify the members of a cultural group while also distinguishing those of another group. The deduction from the above statement is that it is at the level of socialization through varied cultural practices, that a culture is said to be visibly experienced. It is in this regard that music, as one of the fundamental elements of culture, promises abackground for the experience of a given

${ }^{13}$ G. Hofstede, G.J. Hofstede, M. Minkov, Cultures and Organizations: Software of the Mind, New York 1997.

${ }^{14}$ K.A. Zimmermann, What Is Culture?, 2017, https://www.livescience.com/21478-what-isculture-definition-of-culture.html [access: 20.4.2021].

${ }^{15}$ C. Okam, Women, Women, Culture and Development: An Examination of the Role of Theatre for Development in the Evaluation of the Millennium Village Project, Pampaida - Nigeria, "Jotams: A Journal of Theatre and Media Studies" 2016, 1 (2).

${ }^{16}$ Center for Advanced Research on Language Acquisition, What is culture?, 2019, https://carla. umn.edu [access: 4.4.2021]. 
ethnic group and in this case, the Urhobo ethnic group. There are different Urhobo music genresthat exist orally and majority are in recorded form.

\section{Urhobo Music Broadcast on Radio Stations}

One medium music is broadcast is via the radio. As a mass communication medium, the radio has been described as that instrument used for the transmission and reception of electromagnetic waves of radio frequency especially those carrying sound messages. The stated concept of the radio aligns with the characteristics of music. In simple terms, music means any agreeable sounds. In complex terms, music deals with an artistic form of auditory communication incorporating instruments or vocal tones in a structured and continuous manner. Music is available in private homes as well as public places, facilitated through the agency of the radio. Music practitioners and professionals advertise their different tracks via the radio and this is applicable to indigenous music.

Okorie $^{17}$ finds that the radio is used to promote indigenous music. This development is made possible because $80 \%$ of local content is expected to be broadcast as required by the 1992 deregulation of the broadcast industry in Nigeria, a code enacted to guide broadcast content. This is in respect of the fact that there is a noticeable flood of western music content over local indigenous music as a result of the commercial nature of the industry. The variation in broadcast of contents between local and western music is the main focus of the author, using the capital $90.9 \mathrm{fm}$, leading as a case study. The study adopts both the qualitative and quantitative method of gathering data to arrive at the finding of the study. In-depth interview, documentary, observation and a total of 355 copies of questionnaire were distributed in Narayi Highcost, Kaduna State concerning their perception of the extent to which Capital $90.9 \mathrm{fm}$ has promoted our indigenous music. Findings from the study show that Capital $90.9 \mathrm{fm}$ has not really complied with the national broadcast code concerning the airing of local content with emphasis on indigenous music. The study also discovers that there exists a communication gap in what the aim of the local content is meant to achieve, which has led to a conflict between the policy makers and the station. The deduction from the finding of the study suggests that the radio is a veritable medium for the broadcast of indigenous music such as Urhobo Disco music. In other words, audiences can listen to Urhobo Disco music on radio channels such as $88.8 \mathrm{fm}$ Radio Delta, Warri and $95.1 \mathrm{fm}$, Jeremi, as case studies in this current paper. The degree of compilation of Urhobo

17 I. Okorie, Radio and the Promotion of Indigenous Music: An Appraisal Capital 90.9FM Kaduna, Nigeria, Zaria 2015. 
music being aired by the two radio stations is a major objective that is determined in this study.

Larry Thomas states that the radio plays an important role in the life of a human. He refers to the broadcast of music as that which contributes to the affective aspect of human life. The radio also aids the sharing of human experiences with other neighbouring societies ${ }^{18}$. According to Thomas, the radio remains accessible when other modes of communication go down in emergencies. This means that many people in different locations can tune to the radio for the enjoyment that comes from music. This finding corresponds with the study by Familus and Owoeye. Their study finds that radio is the most important instrument in information dissemination. They discover that radio messages and programmes, including the broadcast of music reaches a larger percentage of the people irrespective of their location ${ }^{19}$. They also observe that the use of the radio is important because it promotes the level of awareness of the people on socio-political and economic issues and that it also enables people to be adequately informed about programmes and activities of the government. Therefore, its adoption to harness the cultural experiences of an ethnic group such as the Urhobos cannot be overemphasized.

\section{Urhobo Disco: A Genre of Urhobo Musical Experience and Performance}

Nearly all Urhobo music belongs to the dance music performance and it is experienced in social settings such as burials, in-laws greeting, traditional marriage, naming and children dedication and other vital events of the Urhobo, showcasing the rich cultural heritage of the people. Worthy of mention is that dance music is described as the most composed specifically to facilitate or accompany dance. Grimot says that Urhobo Disco music belongs to the family of the dance music ${ }^{20}$. Urhobo Disco music is performed as a whole musical piece or part of a larger musical arrangement. He finds that in terms of performance, the major categories are live dance music and recorded dance music. The fact that the performance is recorded as indicated by Grimot means it is available for broadcast by radio stations, whose cultural music compendium consists of Urhobo Disco music.

${ }^{18}$ L. Thomas, Radio Plays an Important Role in Our Lives, 2011, https://psc.apcointl. org/2011/09/21/radio-plays-an-important-role-in-our-lives/ [access: 19.3.2021].

${ }^{19}$ E.B. Familusi, P.O. Owoeye, An Assessment of the Use of Radio and other Means of Information Dissemination by the Residents of Ado-Ekiti, Ekiti-State, Nigeria, "Library Philosophy and Practice" 2014, https://digitalcommons.unl.edu [access: 20.3.2021].

${ }_{20}$ N. Grimot, Okpan Arhibo: A Traditional Kind of Disco Music, 2019, https://grimotnanezine. com/2019/10/01/okpan-arhibo-a-traditional-kind-of-disco-music/ [access: 17.3.2021]. 
The Urhobo Disco music is a kind of traditional music attributed to the invention of Chief Okpan Arhibo. This kind of traditional music came to be experienced among the Urhobos as a new musicphenomenon. A sentiment hit by Okpan Arhibo was the "Catch Fire Dance" of the early 1980. The hit was able to change the style, approach, spontaneity and permissiveness within the Urhobo nation and the wider Delta State arena of music and dance. Grimot provides an assessment of the Okpan Arhibo Disco musical performance and its influence of a majority of Urhobo, the greater population of Urhobo youth. According to him, Until Okpan came along with his hits, Urhobo youths who were desperate to be "civilized" (westernized) had rejected the traditional music form. It was Okpan who made Urhobo music acceptable to the youths; his music found the youth and turned them ${ }^{21}$.

The analysis provided by Grimot on the influence of Urhobo Disco music performed by Okpan Arhibo points to the fact that Urhobo Disco music is an alternative to the western Disco music. The preference of the Urhobo Disco music by most Urhobo youths and people indicates that the music contributes to the Urhobo people's experience to that of the western music, whose lyrics are difficult to understand by a majority of the Urhobo people due to language barrier. Thus, listening to Urhobo Disco music either during live performances, recorded and aired via the radio increases the admiration for the Urhobo traditional music as an added value of the people's experience. In this regards, radio stations all find it useful to broadcast Urhobo disco music as performed by OkpanArhibo in their radio stations to attract the Urhobos to their daily programme on radio.

The differences between Urhobo Disco music by Okpan Arhibo and western Disco music is also contrasted by Grimot. He reveals that if Okpan was playing live and one had a western Disco music section, spinning tunes from Michael Jackson, Rick James, Dynasty, The Whispers, Diana Ross, Shalamar and the likes at that event, the youth according to him, would display a preference for Okpan. He observes that Urhobo Disco is probably the happiest music form found to have been played for the entertainment of the Urhobos he has ever experienced. He says that this music genre or Urhobo music perhaps was the first peak in Okpan's music. In characteristic term, the music seems to have generated a virulent dance bug, highly contagious. It appears to be a merely a dance itch people, particularly youths, did not know they had. As valuable as the music has psyched the youth, it is also necessary for radio broadcasting stations to take advantage of the music by

${ }^{21}$ N. Grimot, Okpan Arhibo: A Traditional Kind of Disco Music, 2019, https://grimotnanezine. com/2019/10/01/okpan-arhibo-a-traditional-kind-of-disco-music/ [access: 17.3.2021]. 
giving sufficient time to airing the OkpanArhibo traditional kind of disco music, to redirect the Urhobo youths to their cultural heritage as they listen to and dance to the Urhobo Disco music.

\section{Music Broadcast on Radio and the Socio-cultural Experience of the Urhobo People}

Music is used in diverse settings that are compatible with people's experiences. John Lieff states that music has a central role in human society because it so strongly evokes feelings and affects social activities and interactions ${ }^{22}$. Chris James reveals that music and society have always been intimately related. He finds that music reflects and creates social conditions-including the factors that either facilitate or impede social change ${ }^{23}$. He observes that development of recording/broadcasting of music techniques in the latter half of the $20^{\text {th }}$ century has revolutionized the extent to which most people have access to music. He says that all kinds of music are available to most people 24 hours a day, at the touch of a switch.

The social experience of music by a given people, including the Urhobo music is not limited to live performances by the musicians. The instrumentality of the radio has aided the social experience of music by the people. This is because most radio broadcasting station devote airtime to cultural music for the benefit of the ethnic group in their catchment area of operation as an aspect of their social responsibility to their host communities. In other words, music broadcast via the radio makes it easy for audience to interact with the music of their interest. The radio is about companionship and the emotional connection with the listener. The radio is a valuable access and an asset to the music industry as well. Radio broadcasts of music provide real-time entertainment, news and songs. As an effective medium, broadcast of music on radio leads to the spread of different types of music, including Urhobo Disco music popularized by Chief Okpan Arhibo.

The University of Minnesota (2020) indicates that the radio is used to share and spread regional sounds as experienced by the people. It finds that there is promotional power inherent in the radio because it gives regional music an immense boost. Their finding reveals that local radio stations often carried out their own programmes featuring the popular music of the area. It is against this backdrop that stations such as Radio Jeremi (JFM) 95.1 and Melody FM 88.6, Warri, are

22 J. Lieff, Music Stimulates Emotions Through Specific Brain Circuits, 2014, https://jonlieffmd. $\mathrm{com} / \mathrm{blog} /$ music-stimulates-emotions-through-specific-brain-circuits [access: 19.4.2021].

${ }^{23}$ Ch. James, Music Makes Our Lives Magical and Meaningful, 2008, https://musicmagic.wordpress.com [access: 19.3.2021]. 
selected, as sample radio stations in the Urhobo region that show interest in the broadcast of Urhobo music during their schedule of programmes. The history of these stations illustrates the ways in which radio is used to promote the Urhobo socio-cultural heritage and experience in Nigeria.

Radio Jeremi (JFM), with the slogan "the classic station and the best there is", is a private radio station sited in Otu-Jeremi in Ughelli-South Local Government Area of Delta State. It is established by Prince George N. Ugen, the Managing Director. Its broadcast of programmes extends beyond the Niger Delta region. It means that, any time Urhobo music is broadcast on JFM 95.1, the residence of Urhobo people across the Niger are able to share in the experience portrayed by the music being aired. Melody FM, 88.6 on the other hand is owned and operated by the Delta State Government. It is sited in Warri, the commercial city of Delta State. This radio station has existed for a very long period of time and has regular programmes devoted to the broadcast of Urhobo music. However, the degree at which some Urhobo music genre such as the Urhobo Disco music are aired among the compendium of music at the disposal of the radio stations is determined by how trendy the song is nationwide. Once a song begins to chart more, those songs will get more play time. He observes that the factor is also based on request and promotion from the labels ${ }^{24}$. The degree ofthe consideration of Urhobo Disco music by the select stations for this study is the essence of this investigation.

\section{Field Report, Analysis and Discussion of Findings}

The field investigation is carried out in line with the objective of the paper. The investigation is also guided by the subject matter, which centers onthe roles of the radio stations in popularizing the genre and the degree at which Urhobo (Disco) music is scheduled for broadcast from the compendium of music at the disposal of the selected radio stations in the area where the investigation was undertaken. It attempts to examine the role of the radio in sharing the experience of Urhobo people via the broadcast of traditional music such as the Urhobo Disco music by Chief Okpan Arhibo. In order to carry out the field survey, the researcher engages the Managements of JFM Radio 95.1 (private) and Melody FM Radio 88.6 (public), respectively, in a number of interactive sessions.Data were collected from them, using a Broadcaster Professional Self-Respondent Interview Questionnaire (BPSRIQ). The generated data are presented in the following:

${ }^{24}$ C. Onyeji, Popular Music: Facts about the Music and Musicians, [in:] E. Idolor (ed.) Music in Africa, Ibadan 2002. 
Table 1. A Compendium of Urhobo Music Scheduled for Broadcast in Public and Private Radio Stations

\begin{tabular}{|c|l|c|c|c|c|}
\hline \multirow{2}{*}{ S/N } & \multirow{2}{*}{ Rotated Music List } & \multicolumn{4}{|c|}{ Rating Scale } \\
\cline { 3 - 6 } & & Very Often & Often & Not often & $\begin{array}{c}\text { Not very } \\
\text { often }\end{array}$ \\
\hline 1 & Okpan Arhibo & $\sqrt{ }$ & & & \\
\hline 2 & Johnson Adjah & & $\sqrt{ }$ & \\
\hline 3 & Omokomoko Sokpah & & $\sqrt{ }$ & & \\
\hline 4 & Go-Slow & & $\sqrt{ }$ & & \\
\hline 5 & Evokafua & & $\sqrt{ }$ & \\
\hline 6 & Lady Rose & & $\sqrt{ }$ & & \\
\hline 7 & Sally Young & & $\sqrt{ }$ & & \\
\hline 8 & Lucky Okwe & $\sqrt{ }$ & & & \\
\hline 9 & Solo Kings & $\sqrt{ }$ & & \\
\hline 10 & Egbeku & & & & \\
\hline
\end{tabular}

Source: Management of JFM Radio - 95.1, Otu-Jeremi and Melody FM Radio - 88.6, Edjeba, Warri (2020)

The responses as shown in Table 1 is based on the request that the Management of the radio stations kindly provide a compendium of Urhobo music rotated for broadcast in their respective stations. They were also requested to rate eachof the Urhobo music genres and how often they arescheduled for broadcast. Data presented in Table 1 indicates ten (10) listed Urhobo music rotated for broadcast in the different radio stations. The rating on the scheduled broadcast of Urhobo music is as follows:

Table 2. Showing Analysis of Urhobo Music Scheduled for Broadcast on Radio

\begin{tabular}{|c|l|c|c|}
\hline S/n & \multicolumn{1}{|c|}{ Classification } & Rating & \multirow{2}{*}{ Rank } \\
\hline 1 & Okpan Arhibo & Fery Often \\
\hline 2 & Johnson Adjah & Very Often & \multirow{2}{*}{ Second } \\
\hline 3 & Omokomoko Sokpah & Very Often & \multirow{2}{*}{ Often } \\
\hline 4 & Go-Slow & Often & \multirow{2}{*}{ Third } \\
\hline 5 & Evokafua & Often & \\
\hline 6 & Lady Rose & Often & \\
\hline 7 & Sally Young & Often & \\
\hline 8 & Lucky Okwe & Not Often & \\
\hline 9 & Solo Kings & Not Often & \\
\hline 10 & Egbeku & & \\
\hline
\end{tabular}

Source: Field Survey by the Researcher (2020) 
The analysis provided in Table 2 indicates the ranking of Urhobo music scheduled for broadcast on JFM Radio 95.1 and Melody FM 88.6 respectively. It is shown that Urhobo music scheduled on radio consists of three classifications as follows; Very Often scheduled Urhobo Music is credited to the music of Okpan Arhibo (Disco Music), Johnson Adjah and Omokomoko Sokpah as the top rankers among the list of Urhobo music aired on radio. The second rank of scheduled Urhobo music that is Often aired on radio belong to Go-Slow, Evokafua, Lady Rose, Sally Young and Lucky Okwe. The third class of Urhobo music Not Often rotated for broadcast are those of Solo Kings and Egbeku. Thus, Okpan Arhibo top the Urhobo music very often rotated for broadcast on radio. This result points to the fact that Urhobo Disco by Okpan Arhibo is a popular Urhobo music genre that provides the background for the sharing of the experience of Urhobo people in Delta State. This finding is corroborated by the Manager of Melody FM 88.6, Chief Nuvie Emore. According to him, preference for Urhobo Disco music by a majority of Urhobo people is based on the need to balance the audience' choice. He adds that the State government, through the Programmes department, chose to balance the audience in a bid to satisfying the different tribes in the State. On the contrary, Prince N.G. Ugen of JFM Radio 95.1 observes that Western Disco music is the most preferred genre of music broadcast for entertainment. He states that most radio listening audience are in the age bracket of 15 to 50 years. He finds that this population of age group hardly understands the Urhobo language and hence, they prefer to listen to music genres that are foreign. The implication is that the age of the audience accounts for their preference of the music genre (Urhobo Disco or Western Disco) they listen to.

Table 3. Presentation of Data on the Role of the Radio in the Broadcast of Urhobo Disco Music in Varied Socio-cultural Contextual Experiences

\begin{tabular}{|c|l|c|c|c|c|}
\hline \multirow{2}{*}{ S/N } & \multirow{2}{*}{$\begin{array}{c}\text { Socio-cultural Contextual } \\
\text { Experience }\end{array}$} & Very Highly & Highly & Not Highly & $\begin{array}{c}\text { Not Very } \\
\text { Highly }\end{array}$ \\
\cline { 5 - 6 } & & $\sqrt{ }$ & & & \\
\hline 1 & Burial Ceremony & $\sqrt{ }$ & & $\sqrt{ }$ & \\
\hline 2 & In-Law Greeting & & & $\sqrt{ }$ & \\
\hline 3 & Chieftaincy Title & & & $\sqrt{ }$ & \\
\hline 4 & Child Dedication & & $\sqrt{ }$ & \\
\hline 5 & Birthday Ceremony & & $\sqrt{ }$ & \\
\hline 6 & Political Rally & & & & \\
\hline 7 & Marriage Ceremony & & & & \\
\hline
\end{tabular}

Source: Management of Radio Station (2020) 
Participants were made to respond to the question on the extent to which their Radio stations employed Urhobo Disco music broadcast as a veritable means for sharing the socio-cultural experiences of the Urhobo people in varied contexts. They were made to respond to the extent their different stations performed in the broadcast of Urhobo music covering the listed socio-cultural contexts as experienced by the Urhobo people. Seven socio-cultural contexts were examined as shown in Table 3. The rating scale used to measure the performance of the broadcasting station on the variables reveals the following results: burial ceremonies and in-law greeting are rated very high,political rallies and marriage ceremonies ranked second, as they are rated during schedule of music broadcast. Among ceremonies not highly rated for broadcast includes, chieftaincy title-taking, child dedication and birthday ceremonies. This result shows that burial and in-law greetings, birthday and marriage ceremonies are socio-cultural settings that often prompt the broadcast of Urhobo Disco music on radio. These are contexts where the Urhobo people share their experiences on radio. Based on this result of analysis, the question is answered that music is a veritable means of sharing the socio-cultural experiences of the Urhobo people in the aforementioned contexts via the radio.

Outside the management of the two radio stations, interview sessions were also conducted for twenty-five (25) participants. The interview focuses on the Social Affective Experience of Urhobo Disco music that are broadcast on radio. Participants were required to respond to ten (10) interview questions to measure the extent to which they agree or disagree based on a 4-point rating scale of the Likert moderated type to determine the level of response to the interview question items, where Strongly Agree $(\mathrm{SA})=4$, Agree $(\mathrm{A})=3$, Disagree $(\mathrm{D})=2$ and Strongly Disagree $(\mathrm{SD})=1$.

Table 4 presents the analysis of responses of participants using the mean score and standard deviation simple statistics to determine the extent to which participants' opinion is towards the social affection experienced by Urhobo people as the audience listening to Urhobo Disco music genre on radio. The 2.5 mean score benchmark was employed for making decision on the moderated Likert rating scale of 4 points. The following results are obtained from the data that were subjected to analysis.

Result on item 1 indicates that participants strongly agree to the tone of 3.27 mean at 0.81 standard deviation accepting the statement that it gives them pleasure listening to Urhobo music on radio. In item 2, participants strongly agree with a high mean of 3.31 and a standard deviation of 0.82 which suggests that participants accept the fact that broadcast of music enhances the Urhobo language. This is made possible because of the song text of the Urhobo Disco music which are performed with the Urhobo language, and listeners are able to deduce the meaning in the song texts. Responses on item 3 also accept as shown in the mean 


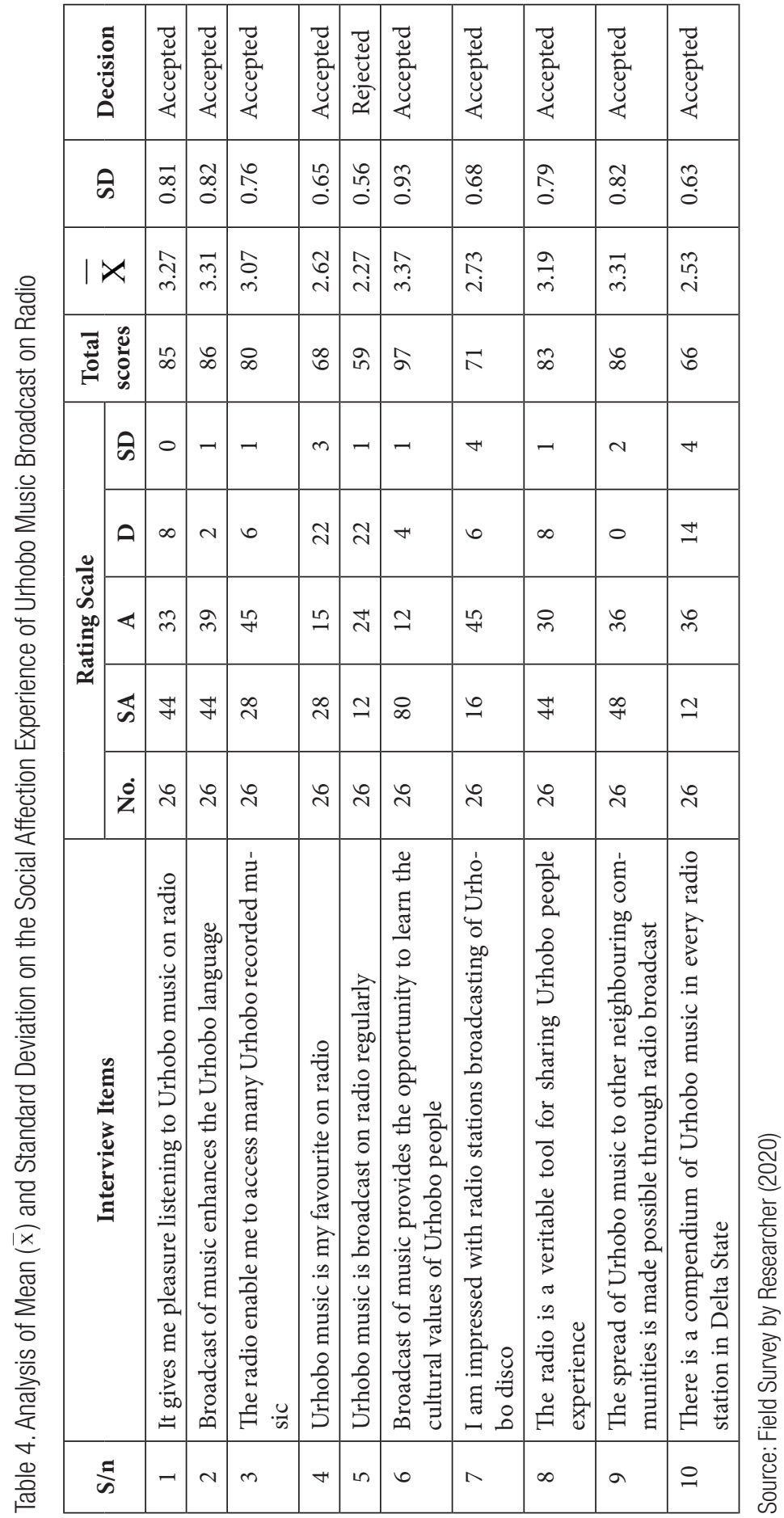


of 3.07 and a standard deviation of 0.76 , meaning that participants strongly agree that the radio enables individuals to access many Urhobo recorded music. The following results are obtained on item 4 , where mean $=2.62$ and standard deviation is 0.65 , meaning that participants accept that Urhobo music is their favourite on radio. Participants appear to strongly disagree to the statement in item 5 as indicated by the mean of 2.27 and standard deviation of 0.56 , meaning thatUrhobo music is not broadcast on radio regularly. This finding is supported by the fact that there are other ethnic nationalities as listening audience to radio programmes that have to be satisfied. Item 6 is positively responded to by participants as shown in the mean of 3.73 and standard deviation of 0.93 , agreeing that broadcast of music provides the opportunity to learn the cultural values of the Urhobo people. The opinion of participants on item 7 with the mean of 2.73 and standard deviation of 0.68 supports the statement that they were impressed with radio stations broadcasting Urhobo Disco. This finding aligns with the view of Chief Nuvie Emore who agrees that he prefersUrhobo music to Western Disco music on radio. On item 8, the result of mean obtained is 3.19 and standard deviation of 0.79 . Based on this result, it is accepted very strongly by participants that the radio is a veritable tool for sharing the cultural experiences of the Urhobo people. This is made possible because the radio is a medium of mass communication capable of reaching the remotest location of our people, thereby connecting the rural and urban cities to participate in the experience of the Urhobo people through music broadcast on radio. The statement on item 9 is accepted as shown by the results where the mean $=3.31$ and standard deviation $=0.82$, that the spread of Urhobo music to other neighbouring communities is made possible through radio broadcast. There is a minimal agreement by participants on item 10 as seen by the result of the mean of 2.53 and standard deviation of 0.63 , thus supporting the notion that there is a compendium of Urhobo music in both private and public radio station as demonstrated by JFM radio 95.1 and Melody FM 88.6 respectively with a compendium of Urhobo music available for schedule during broadcast of Urhobo music that have assisted the presentation of the Urhobo people cultural experience.

\section{Conclusion}

Urhobo people have various platformsfor exhibiting their cultural and social experiences. The rich cultural heritage is experienced through their musical performance. Urhobo music, which includes Urhobo Disco, is preferred by a majority of Urhobo people because it is the most ideal music that corresponds with their cultural and social experiences. Urhobo Disco music is highly valued and cherished as it is very often performed live on stage and on broadcast on radio during 
burials, in-law greetings, political rallies and marriage ceremonies respectively. These socio-cultural contexts employ Urhobo music for their entertainment and social interaction. In the process the cherished values and customs that were experienced by generations past are replicated and transmitted. Therefore, the music of Urhobo, including Urhobo Disco, ensures that the cultural experiences of the Urhobo people is sustained, shared, documented and transmitted via the medium of the radio broadcast of music. Thus, the paper concludes that the compendium of Urhobo music by major radio stations has enabled the spread of the cultural and social experiences of the Urhobo people beyond their region. This is because, the compendium of the Urhobo music allows for rotation and schedule of music for broadcast. Also, the compendium of Urhobo music enables the radio stations to avoid monotonous use or repeatedly airing one type of Urhobo music genre in every programme.

\section{Bibliography}

Altanba J., Forsythe W., The Role of Cultural Schemata in Reading Comprehension, "Advances in Psychology" 1993, 103.

Center for Advanced Research on Language Acquisition, What is culture?, 2019, https://carla.umn. edu [access: 4.4.2021].

Dawn J., Promoting Cultural Diversity: African Music in Australian Teacher Education, "Australian Journal of Music Education” 2016, 50 (2).

Ekwueme L., Essays on African and African-American Music and Culture, Lagos 2004.

Familusi E.B., Owoeye P.O., An Assessment of the Use of Radio and other Means of Information Dissemination by the Residents of Ado-Ekiti, Ekiti-State, Nigeria, "Library Philosophy and Practice" 2014, https://digitalcommons.unl.edu [access: 20.3.2021].

Grimot N., Okpan Arhibo: A Traditional Kind of Disco Music, 2019, https://grimotnanezine. com/2019/10/01/okpan-arhibo-a-traditional-kind-of-disco-music/ [access: 17.3.2021].

Hofstede G., Hofstede G.J., Minkov M., Cultures and Organizations: Software of the Mind, New York 1997.

IGI Global, What is Cultural Experiences, 2020, https://www.igi-global.com [access: 17.3.2021].

James Ch., Music Makes Our Lives Magical and Meaningful, 2008, https://musicmagic.wordpress. com [access: 19.3.2021].

Thomas L., Radio Plays an Important Role in Our Lives, 2011, https://psc.apcointlong.org [access: 19.3.2021].

Lieff J., Music Stimulates Emotions Through Specific Brain Circuits, 2014, https://jonlieffmd.com/blog/ music-stimulates-emotions-through-specific-brain-circuits [access: 19.4.2021].

Malcolm I.G., Sharifian F., Aspect of Aboriginal English Oral Discourse. An Application of Cultural Schema Theory, "Discourse Studies" 2002, 4 (2).

Nishida H., Cultural Schema Theory, [in:] W. Gudykunst (ed.), Theorizing about Intercultural Communication, Thousand Oaks 1999.

Odogbo M., Ojo E., Research Methods in the Humanities, Lagos 2003. 
Okam C., Women, Culture and Development: An Examination of the Role of Theatre for Development in the Evaluation of the Millennium Village Project, Pampaida - Nigeria, "Jotams: A Journal of Theatre and Media Studies" 2016, 1 (2).

Okorie I., Radio and the Promotion of Indigenous Music: An Appraisal Capital 90.9FM Kaduna, Nigeria, Zaria 2015.

Okpadah S., Aesthetic Language of Communication in Urhobo Culture, [in:] K. Eni, B. Binebai, S. Ikibe (eds.), Music Scholarship, Culture and Performance Challenges in $21^{\text {st }}$ Century Africa: A Critical Resource Book in Honour of Emurobome Idolor, Lagos 2016.

Okpadah S., Urhobowood Home Videos and the Poetics of cultural documentation, [in:] M. Tugbokorowei, C. Anyanwu (eds.), New Aesthetic Dimensions in African Drama and Theatre: A Festschrift in Honour of Prof Sam Ukala, Delta State 2018.

Onyeji C., Popular Music: Facts about the Music and Musicians, [in:] E. Idolor (ed.) Music in Africa, Ibadan 2002.

Peters J., Speaking Into the Air, Chicago 1999.

Shahghasemi E., Cultural schema theory, [in:] Y. Kim, K. McKay-Semmler (ed.), The International Encyclopedia of Intercultural Communication, vol. 1, New York 2018.

Strandell J., The Cultural Schema: Towards Conceptual Compatibility in Culture-Cognition Interaction Research, Doctoral dissertation, University of Copenhagen, Copenhagen 2017.

UNESCO, Performing Arts (Such as Traditional Music, Dance and Theatre), 2016, https://ich.unesco. org/en/performing-arts-00054 [access: 30.3.2021].

University of Minnesota, Understanding Media and Culture, 2020, https://open.lib.umn.edu/mediaandculture/ [access: 30.3.2021].

Zimmermann K.A., What Is Culture?, https://www.livescience.com/21478-what-is-culture-definition-of-culture.html [access: 20.4.2021]. 